\title{
SEOPA-1 and GOLGI-2 Apricot Seedlings Are Resistant to Plum Pox Virus
}

\author{
María L. Badenes, Jose Martínez-Calvo, and Gerardo Llácer \\ Instituto Valenciano de Investigaciones Agrarias, Apartado Oficial 46113, \\ Moncada, Valencia, Spain
}

Additional index words. Prunus armeniaca, fruit breeding, plum pox potyvirus, sharka

Apricot (Prunus armeniaca L.) production was 2.8 million tons in 2001 (FAO, 2001), making it the third most important stone fruit species worldwide. However, the spread of Plum Pox Virus (PPV), also known as sharka, is the most important limiting factor to the apricot industry in Europe. During the 1980s and 1990s, apricot production was seriously affected by PPV in Spain, France, and Italy (Roy and Smith, 1994). Apricot is very sensitive to all strains of PPV, resulting in serious damage to the fruits (deformation, necrotic spots on pits and flesh, and dry flesh). PPV is spread by aphids in a nonpersistent way: acquisition time by the aphids lasts seconds, retention lasts minutes and the virus is transmitted via the stylet (Nault, 1997). This fact makes chemical control of the aphid vector inefficient. Removal of infected trees was ineffective in eradicating the disease in Spain (Llácer and Cambra, 1998). The only reliable control of the PPV is to use resistant cultivars. However, there are no resistant cultivars adapted to the mild winters in southern Europe.

The Instituto Valenciano de Investigaciones Agrarias (IVIA) apricot breeding program has developed two seedling selections, SEOPA-1 and GOLGI-2, with resistance to PPV, and adapted to mild winters. These selections have the potential for inclusion in breeding programs where PPV resistance is an objective. They are early-ripening, productive and have better fruit quality than existing native cultivars from Valencia, and warrant limited introduction for further evaluation under commercial production practices.

\section{Origin}

SEOPA-1, selected at IVIA in 1997 from a cross made in 1994 between 'Stark Early Orange' (seed parent) and 'Palau' (pollen parent), was tested as SEOxP94-2. GOLGI-2, selected at IVIA in 1997, from a progeny of 'Goldrich' (seed parent) $X$ 'Ginesta'(pollen parent) was tested as GxG 94-1. 'Stark Early Orange' and 'Goldrich' were the donors of PPV resistance

Received for publication 27 Nov. 2001. Accepted for publication 28 May 2002. We thank Rafael Ros, Tarek A. Moustafá, and Dolores M. Archelós for assistance in data collection during the evaluation of these cultivars and J.R. Clark for revision an improvement of the MS. The apricot breeding project was funded by the Comisión Interministerial de Ciencia y Tecnología (AGF 98-0991-C02).
(Audergon et al., 1995; Dosba et al., 1991). 'Palau' and 'Ginesta' are early native cultivars from Valencia, as described by Badenes et al. (1997).

The seedling selections were tested at IVIA for four cropping years, from 1998 to 2001. IVIA is located Northwest of Valencia, lat. $39^{\circ} 34^{\prime} \mathrm{N}$ and long. $0^{\circ} 24^{\prime} \mathrm{W}, 55 \mathrm{~m}$ above sea level. The soil was a sandy loam with a pH 7.8, Xerorthent type according to Soil Survey Staff (1975) taxonomy. The mean annual rainfall at this location is $460 \mathrm{~mm}$ distributed in the spring and fall. The average temperature is $16.4{ }^{\circ} \mathrm{C}$, the highest and lowest temperatures were $41{ }^{\circ} \mathrm{C}$ recorded in Aug. 1994 and -3.2 ${ }^{\circ} \mathrm{C}$ recorded in Jan. 1995, respectively. Trees were trained to an open-center system, spaced $3 \mathrm{~m}$ between trees in rows $5 \mathrm{~m}$ apart, and grow under standard cultural practices for this production area. Drip irrigation was applied to the orchard as needed, based on ETP calculations provided by Ferrer et al. (1994). Each year for four cropping years, average fruit weight, fruit size, and three color measurements (ground, blush, and flesh color) were determined on a random sample of 25 fruits. Firmness was measured on opposite sides of the fruit (the skin was removed) using a model 4301 (Instron Universal Machine, Buckinghampshire, U.K.) equipped with an 8-mm-diameter cylindrical plunger, and the force required to penetrate the plunger $5 \mathrm{~mm}$ into the fruit flesh was recorded in $\mathrm{kg} \cdot \mathrm{cm}^{-2}$. Duplicate samples of mesocarp tissue derived from 30 fruits were homogenized in a blender, filtered through cheesecloth, and the juice or filtrate was used for determination of sugar and acids. Percentage of soluble solids were measured with a refractometer (model 3410-J03, ATAGO, Japan). Total acid was determined by titration to $\mathrm{pH} 7.0$ with $0.1 \mathrm{~N}$ $\mathrm{NaOH}$ and data were expressed as grams per liter of malic acid equivalent. Flowering and ripening seasons were also recorded for the same 4 years.

\section{Screening for PPV resistance}

Resistance to PPV was tested following the procedure described by Audergon and Morvan (1990) improved by Moustafa et al. (2001) and used in France by Dosba et al., (1991; 1992); Audergon et al., (1995). This test is now used by most apricot breeding programs aimed at introducing PPV resistance. Budwood from each of the apricot seedling selections SEOPA-1 and GOLGI-2 was grafted onto PPV-infected 'GF-305' peach seedlings. In previous work, we used all the PPV strains described for apricot (i.e. Dideron, Marcus, and El Amar) for testing the resistant parents and selected seedlings. Both resistant parents ('Stark Early Orange' and 'Goldrich') were resistant to all strains tested. Resistant seedlings had a similar response to all strains tested as their resistant parents. No differences in response were found among strains used. Consequently, the PPV Dideron strain 3.3 RB characterized and described by Asensio (1996) which is commonly found in Spain was used in the standard procedure. After grafting, six plants per cultivar were held for 2 months in the dark at $4{ }^{\circ} \mathrm{C}$ to meet chilling requirements for budbreak, then moved to a greenhouse at $25^{\circ} \mathrm{C}$ to promote new growth. No virus symptoms were observed in the new growth on any trees of these apricot selections. Leaf tissue was tested using enzyme linked immunosorbant assay (ELISA) and PCR analysis, as described in Olmos et al. (1997) and accepted in the European Union protocol for virus detection and quarantine. Although erratic distribution of PPV in the plant, this protocol for detecting PPV can detect very low amounts of virus. Following this methodology, PPV was not detected in any grafted plant of these selections. Plants were then subjected to a second chilling treatment and tested again, following budbreak with same results. To determine whether translocation of the virus through the apricot occurred, a similar test was performed using budwood of SEOPA-1 and GOLGI-2 grafted onto "virus free" peach (GF-305) followed by inoculation of the virus on the apricot as described above. Inoculation was made by grafting a bud from an infected tree (seedling of 'Canino') used for all PPV tests as the source of inoculum. No symptoms were observed in the apricot, but the peach rootstock showed symptoms, indicating there was translocation of the virus from the apricot to the peach but no detectable multiplication of the virus in the apricot. According to Fraser (1990), there is a type of resistance described in plants that show translocation, but not multiplication of the virus. This behavior is observed in these seedlings: the virus can be translocated through the apricot and infect the peach, but did not infect the apricot. PPV was not detected in these selections, consequently, cannot be transmitted from them to other plants. It might be transmitted to susceptible rootstocks, however, it is unlikely that PPV could be transmitted from an infected rootstock to adjacents plants.

An additional test was made by grafting budwood of SEOPA-1 and GOLGI-2 onto an infected apricot (a seedling of 'Canino'), that showed symptoms, was ELISA-positive, and had been used as a source of inoculum for PPV screening. Typical PPV symptoms were observed at the first stages of development of the selection, but when the grafted selections began to grow they recovered from the early symptoms. ELISA and PCR did not detect presence of the virus. This is typical of resistance mediated by RNA (Fagard and Vaucheret, 


\section{Cultivar \& Germplasm Releases}

2000). Similar results were obtained when testing the resistant parents 'Goldrich' and 'Stark Early Orange' (data not published).

No field tests were conducted because field testing is allowed only in those countries such as Greece and Romania, where PPV is endemic. However, Audergon et al. (1995) obtained results in greenhouse experiments which were similar to those obtained in field conditions, thus validating the greenhouse protocol. The greenhouse method allows researchers to evaluate a larger number of plants in a shorter time and to work in controlled conditions avoiding possible introduction or spread of PPV. Field inoculations are not as effective or efficient.

\section{Description}

'SEOPA-1'. Tree vigor is medium, lower than that for 'Palau' (Badenes et al., 1997), and the growth habit is medium-open. Vegetative budbreak date at IVIA was 18 Mar., $16 \mathrm{~d}$ later than 'Palau' (data not shown). Average full bloom date was 7 Mar. (Table 1), 2 weeks later than 'Palau'. This is an important characteristic, allowing flowers to avoid spring frost damage. Intensity of bloom was very high, similar to 'Palau'. Flowers are self-fertile and this cultivar flowers mainly on spurs.

Fruit ripened on average 23 May, $5 \mathrm{~d}$ ahead of 'Palau', the male parent. Consistent cropping was achieved in all four crop years. Fruit averaged $47.3 \pm 1.6 \mathrm{~mm}$ in diameter and weighed $54.6 \pm 2.6 \mathrm{~g}$, being larger and heavier than those of 'Palau' (Table 1) and comparable to 'Cafona' and 'Screara' (Della Strada et al., 1987; Badenes et al., 1998). However, fruit thinning was very light during the first two crop years. In 2000, a year in which more severe thinning was conducted, individual fruit weight was $65.0 \mathrm{~g}$. In commercial orchards thinning will be required to produce large fruits. Fruit shape is cordate, with intermediate cavity depth and suture, and fruits are symmetric along the suture. Fruits have a smooth pubescent skin. The skin is yellow orange (RHS 21-C, Royal Horticultural Society, 1966) with some greenish ground, and a dense blush covering $10 \%$ of the fruit skin (Fig. 1), less than that for 'Palau'. It has fair to good eating quality (Table 2), slightly better than 'Palau', but much better than 'Goldrich'. The flesh is medium-firm, juicy, yellow orange in color(RHS 23-A, Royal Horticultural Society, 1966). Fruits are sweet, with a good balance of acidity, flavor and aroma. Soluble solids content is higher than that for 'Goldrich' but lower than that for 'Palau' (Table 1), while acidity did not show significant differences. The pit does not adhere to the flesh. The stone is ovate and the kernel taste is bitter. Fruit cracking was not observed in four crop years with regular spring rainfall, characteristic of the Mediterranean climate of Valencia.

'GOLGI-2'. Tree vigor is medium, similar to 'Ginesta', with a medium-open growth habit. Vegetative budbreak date at IVIA was 22 Mar., 19 d later than 'Ginesta'. Average full bloom date was 1 Mar. (9 d later than 'Ginesta'). Intensity of bloom was high, but slightly lower
Table 1. Bloom, maturity dates and fruit characteristics of apricot cultivars at IVIA, Valencia, Spain (1998-2001). Data are averages of 4 years (1998-2001) for the selections and three years for the parents. Due to the high chilling requirements of 'Stark Early Orange', it was not possible to gather fruit data at IVIA, Valencia.

\begin{tabular}{|c|c|c|c|c|c|c|}
\hline Cultivar & $\begin{array}{c}\text { Full bloom } \\
\text { date }\end{array}$ & $\begin{array}{c}\text { Harvest } \\
\text { date }\end{array}$ & $\begin{array}{l}\text { Fruit wt } \\
\text { (g) }\end{array}$ & $\begin{array}{l}\text { Firmness } \\
\left(\mathrm{kg} \cdot \mathrm{cm}^{-2}\right)^{\mathrm{z}}\end{array}$ & $\begin{array}{c}\mathrm{TSS} \\
\left({ }^{\circ} \mathrm{Brix}\right)^{\mathrm{y}}\end{array}$ & $\begin{array}{l}\text { Acidity } \\
\left(\mathrm{g} \cdot \mathrm{L}^{-1}\right)^{\mathrm{x}}\end{array}$ \\
\hline Goldrich & 3 Apr. & 16 June & $68.8 \mathrm{a}$ & $1.2 \mathrm{~b}$ & $13.5 \mathrm{~d}$ & $23.6 \mathrm{a}$ \\
\hline Ginesta & 20 Feb. & 26 May & $40.2 \mathrm{c}$ & $2.3 \mathrm{a}$ & $15.2 \mathrm{~b}$ & $21.7 \mathrm{a}$ \\
\hline Palau & 21 Feb. & 28 May & $36.4 \mathrm{~d}$ & $1.2 \mathrm{~b}$ & $16.2 \mathrm{~b}$ & $19.4 \mathrm{a}$ \\
\hline SEOPA-1 & 7 Mar. & 23 May & $54.6 \mathrm{~b}$ & $1.2 \mathrm{~b}$ & $14.2 \mathrm{c}$ & $19.3 \mathrm{a}$ \\
\hline GOLGI-2 & 1 Mar. & 2 June & $53.3 \mathrm{~b}$ & $1.0 \mathrm{c}$ & $18.5 \mathrm{a}$ & $24.6 \mathrm{a}$ \\
\hline
\end{tabular}

${ }^{\mathrm{z}}$ Firmness measured with an $8 \mathrm{~mm}$ diameter cylindrical plunger that caused a $5-\mathrm{mm}$ deformation using an INSTRON.

yTSS is total soluble solids

${ }^{\mathrm{x}}$ Acidity expressed as malic acid.

${ }^{\mathrm{w}}$ Means separation within columns by test, $P=0.05$. Means within columns followed by

the same letter are not significanly different.

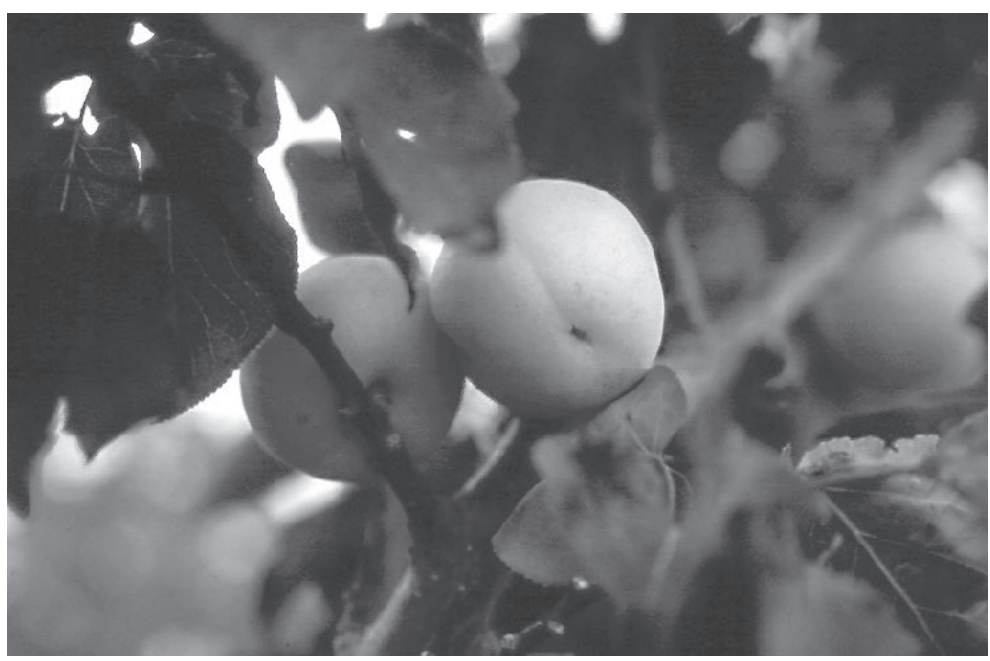

Fig.1. Fruits of SEOPA-1. than 'Ginesta', which typically has a high bloom intensity. Flowers are self-fertile and are mainly borne on spurs.

Fruit ripened at the end of May to the beginning of June, with average ripening date 2 June, $7 \mathrm{~d}$ after 'Ginesta' (Table 1) and a few days ahead of 'Canino'. Consistent cropping was achieved in all 4 years. Fruit averaged $46.3 \pm 1.6 \mathrm{~mm}$ in diameter, and weighed 53.3 g, which was $35 \%$ larger than 'Ginesta' (Table
1). However, thinning was very light in our trial, and in commercial orchards fruit size can be further increased by more severe thinning. Fruit shape is round, with a shallow cavity depth and suture is symmetric along the suture line, and has a smooth pubescent skin. The skin has a yellow ground color with a dense red blush covering $30 \%$ of the fruit (Fig. 2), much less than 'Ginesta' in which red blush covers $90 \%$ of the fruit. Fruit color was RHS
Table 2. Subjective evaluations of fruit and tree characteristics of apricot cultivars and lines. Based on a scale $0-5$, with a rating of $<2.5$ considered unacceptable. Data are means of 4 years at Valencia (1998-2001).

\begin{tabular}{lccccc}
\hline Fruit characteristic & Goldrich & Ginesta & Palau & SEOPA-1 & GOLGI-2 \\
\hline Shape $^{\mathrm{z}}$ & 4 & 4 & 4 & 5 & 5 \\
Skin color $^{\mathrm{y}}$ & 3 & 5 & 5 & 3 & 4 \\
Flesh color $^{\mathrm{x}}$ & 3 & 4 & 4 & 3.5 & 3.5 \\
Sugar/acid balance $^{\mathrm{w}}$ & 1 & 2.5 & 3 & 3.5 & 3.5 \\
Tree vigor $^{\mathrm{v}}$ & 3 & 4 & 4 & 3.5 & 3.5 \\
Health $^{\mathrm{u}}$ & 4 & 4 & 4 & 4 & 4 \\
\hline
\end{tabular}

${ }^{2}$ From round or mostly round, symmetric without pronounced suture (5) to asymmetric, ovate with prononced suture (1).

${ }^{y}$ Rated from uniform ground yellow color, intensive red blush in more than $50 \%$ of the fruit (5), (e.g. 'Ginesta'), to less uniformity ground color and no red blush (1) .

${ }^{\mathrm{x}}$ Color defined as: yellow-orange (4), yellow (3), white (2).

${ }^{\text {w}}$ Higher value indicated equilibrium among sugar acid balance: too acid (1), very acid (2), medium balance sugar acid (3), good sugar acid balance (4), excellent balance (5).

vBased on 2000 measurement of tree circumference at $30 \mathrm{~cm}$ height above ground: $40 \mathrm{~cm}$ or more (5), $35 \mathrm{~cm}$ (4), $30 \mathrm{~cm}(3)$.

"Maximum rating indicates a lower occurrence of diseases, largely based on presence of Monilinia laxa. 


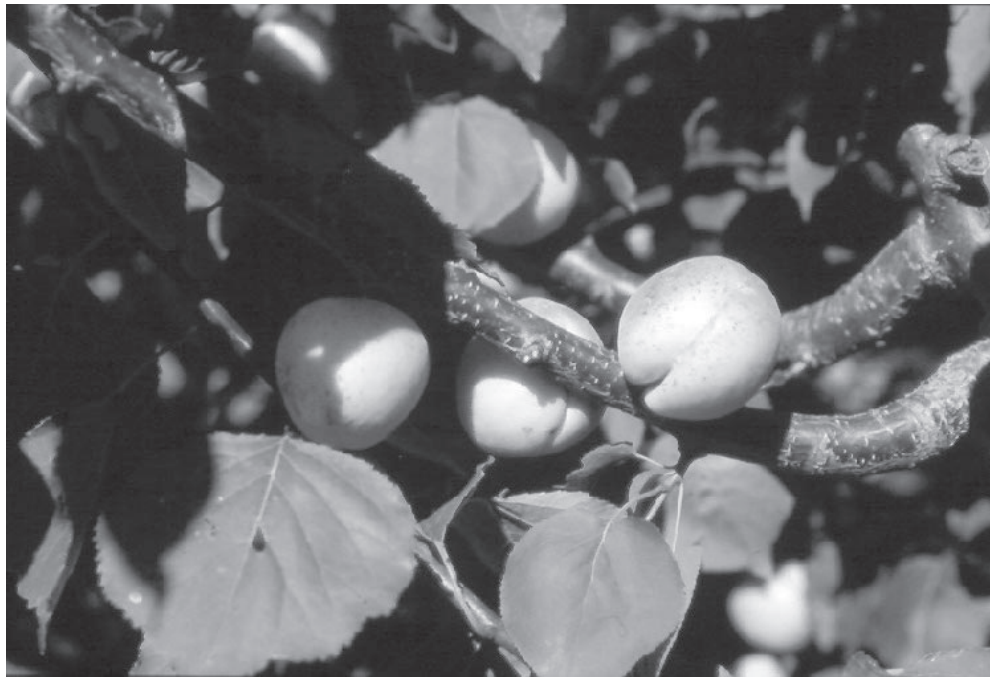

Fig. 2. Fruits of GOLGI-2.

13-C. Fruits have a fair to good eating quality (Table 2). Fruit firmness is medium (Table 1) but lower than that for 'Ginesta' which has very firm fruit. Flesh is juicy, and has a yellow color RHS 13-A. Fruits are sweet with a good combination of acidity, sweetness and aroma. Acidity was not significantly different from the parents but soluble solids content was higher than that of the parents resulting in good flavor. The pit is round, freestone and the kernel is bitter. Fruit cracking was not observed in four crop years.

In a trial with more than 90 cultivars from different countries, including 20 native cultivars from Valencia and Murcia (Spain), SEOPA-1 and GOLGI-2 showed similar field susceptibility to brown rot [Monilinia laxa (Aderhold and Ruhl.) Honey ex. Wetzel] as other cultivars. Susceptibility to bacterial spot caused by [Xanthomonas arboricola pv. Pruni Young, (1996)] was not evaluated since this disease is not present in Spain.

SEOPA-1 and GOLGI-2 might be alternatives to the early ripening cultivars that were removed due to the spread of PPV in Spain. Also, they could be alternatives for other regions, with medium chilling requirements, such as southern Europe, the southern United States, or South America. Both selections performed very well in the last 4 crop years in Moncada where the chilling hours ranged between 400 to 600 calculated according to Richardson et al. (1975).

\section{Availability}

SEOPA-1 and GOLCI-2 have been tested of all known viruses and virus-like organisms by the IVIA stone fruits quarantine program and have been found "virus free". These selections are in the process of registration in the Protected Plant List from The Ministry of Agriculture of Spain. There is no restriction on testing but propagation of these selections for commercial utilizations is prohibited. Currently, limited amounts of budwood, upon request to the authors, are available for research trials.

\section{Literature Cited}

Asensio, M. 1996. El virus de la sharka (plum pox virus): Caracterización, diagnóstico y detección mediante anticuerpos monoclonales específicos. Tesis doctoral, Universidad Politécnica de Valencia, $193 \mathrm{p}$.

Audergon, J.M. and G. Morvan. 1990. A rapid method for assessing the sensivity of apricot to Plum Pox Virus. XXIII Intl. Hort. Congress. Florence, p. 46.

Audergon, J.M., G. Morvan, F. Dicenta, M.G. Chastelliere, and I. Karayiannis. 1995. A method to determine the susceptibility of apricot cultivars to Plum Pox Virus. Acta Hort. 384:575-579.

Badenes, M.L., J. Martínez-Calvo, S. GarcíaCarbonell, D. Villarrubia, and G. Llácer. 1997. Descripción de variedades autóctonas valencianas de albaricoquero. Publicaciones de la Conselleria de Agricultura Pesca y Alimentación de Valencia. Serie Divulgación Técnica
41, 62 p. ISBN: 84-482-1603-02.

Badenes, M.L., J. Martínez-Calvo, and G. Llácer. 1998. Analysis of apricot germplasm from the European ecogeographical group. Euphytica 102:93-99.

Dosba, F., M. Lansac, P. Maison, G. Massonié, and J.M. Audergon. 1991. Plum Pox Virus resistance of apricot. Acta Hort. 235: 275-281.

Dosba, F., S.Orliac, F. Dutranoy, P. Maison, G. Massonié, and J.M. Audergon. 1992. Evaluation of resistance to Plum pox virus in apricot trees. Acta Hort., 309:211-219.

Della Strada, G., F. Pennone, C. Fideghelli, F. Monastra and D. Cobianchi. 1987. Monografia di cultivar di albicocco. Istituto Sperimentale per la Frutticoltura. Roma 355. 239 p.

Fagard, M. and H. Vaucheret. 2000. (Trans)gene silencing in plants: How many mechanisms? Annu. Rev. Plant Physiol. Plant Mol. Biol. 51: 167-194

FAO. 2002. FAOSTAT Agriculture database 2001. Web site at http://apps.fao.org

Ferrer, P.J., V. Cebolla, J.J. Molinero, I. Trenor, J.Soler, F. Legaz and F. Illa. 1994. Un sistema de ayuda a la decisión en la programación de fertirriego en cítricos. SDTA, IVIA. Conselleria de Agricultura, Pesca y Alimentación.

Fraser, R.S.S. 1990. The genetics of resistance to plant viruses. Ann. Rev. Phytopathol. 28: 179-200.

Llácer G. and M. Cambra . 1998. Thirteen years of sharka disease in Valencia, Spain. Acta Hort. 472:379-384.

Moustafa, T.A., M.L. Badenes, J. Martínez-Calvo, and G. Llácer. 2001. Determination of resistance to sharka (plum pox) in apricot. Scientia Hort. 91:59-70

Nault, L.R. 1997. Arthropod transmission of plant viruses: A new synthesis. Annals of the Ent. Soc. Amer. 90 (5):521- 541.

Olmos, A., M. Cambra, M.A. Dasí, T. Candresse, O. Esteban, M.T. Gorris, and M. Asensio. 1997. Simultaneous detection and typing of plum pox potyvirus (PPV) isolates by heminested-PCR and PCR-ELISA. J. Virol. Methods 68:127-137.

Richardson, E.A., S.D. Seeley, and D.R. Walker. 1974. A model for estimating the completion of rest for 'Redhaven' and 'Elberta' peach trees. HortScience 9:331-332.

Roy, A.S. and I.M. Smith. 1994. Plum pox situation in Europe. EPPO Bulletin 24:515-524.

Royal Horticultural Society.1995. RHS Colour Charts. $3^{\text {rd }}$ Ed. Royal Hort. Soc., London.

Soil Survey Staff. 1975. Soil Taxonomy: A basic system of soil classification for making and interpreting soil surveys. Agr. Handbook 436 U.S. Gov. Print. Office. Washington, 754 p.

UPOV .2001. Descriptor for apricot (Prunus armeniaca $\mathrm{L})$. Web site at http://upov.int

Young, L. 1996. Names of plant pathogenic bacteria 1864-1995. Rev. Plant Pathol. 75(9): 721-763. 